\title{
STUDI KOMPARATIF MODEL PEMBELAJARAN PROBING- PROMPTING DAN STUDENT FACILITATOR AND EXPLAINING (SFAE) TERHADAP HASIL BELAJAR FISIKA TEKNIK DITINJAU DARI KREATIVITAS BERPIKIR MAHASISWA TEKNIK INFORMATIKA, STT DHARMA ISWARA MADIUN
}

\author{
Sulistyaning Kartikawati \\ IKIP PGRI Madiun \\ listyosulistyaningkartika@yahoo.co.id
}

\begin{abstract}
ABSTRAK
Penelitian ini bertujuan untuk mengetahui, (1) perbedaan pengaruh model pembelajaran probingprompting dan model pembelajaran student facilitator and explaining (SFAE) terhadap hasil belajar fisika teknik, (2) perbedaan pengaruh kreativitas berpikir tinggi dan rendah terhadap hasil belajar fisika teknik, (3) interaksi antara model pembelajaran probing-prompting dan model pembelajaran student facilitator and explaining (SFAE) dengan kreativitas berpikir terhadap hasil belajar fisika teknik. Penelitian ini dilakukan di Program Studi Teknik Informatika STT Dharma Iswara Madiun. Metode yang digunakan adalah metode eksperimen dengan desain faktorial $2 \times 2$. Teknik pengambilan sampel menggunakan cluster random sampling. Pada penelitian ini yang menjadi sampel adalah dua kelas yaitu kelas $2 \mathrm{~A}$ dengan jumlah 18 mahasiswa sebagai kelas eksperimen I dan kelas 2B dengan jumlah 16 mahasiswa sebagai kelas eksperimen II. Instrumen yang digunakan adalah tes kreativitas berpikir untuk mengukur kreativitas berpikir mahasiswa sedangkan hasil belajar diperoleh dari quiz dengan menggunakan soal tes kognitif. Analisis data meliputi analisis deskriptif dan analisis inferensial. Analisis deskriptif dilakukan dengan menyajikan data melalui tabel distribusi frekuensi dan histogram, sedangkan analisis inferensial digunakan untuk menguji hipotesis. Uji prasyarat analisis menggunakan metode Liliefors, untuk menguji hipotesis menggunakan uji anava dua jalan.Berdasarkan hasil penelitian dengan taraf signifikan $5 \%$ menunjukkan bahwa: 1) tidak ada perbedaan pengaruh model Probing-Prompting dan Student Facilitator and Explaining terhadap hasil belajar fisika teknik; 2) tidak ada perbedaan pengaruh kreativitas mahasiswa tinggi dan rendah terhadap hasil belajar fisika teknik; 3) tidak ada interaksi antara model pembelajaran Probing-Prompting dan student facilitator and explaining dengan kreativitas mahasiswa terhadap hasil belajar fisika teknik.
\end{abstract}

Kata Kunci : Probing-Prompting, Student Facilitator and Explaining (SFAE), Hasil Belajar, Kreativitas Berpikir

\section{PENDAHULUAN}

Berdasarkan hasil observasi diketahui ada kendala dalam pelaksanaan proses pembelajaran yaitu: banyak mahasiswa yang kurang aktif dalam proses pembelajaran, mahasiswa juga belum terlatih dalam menganalisis dan membuat pemecahan masalah dalam mengerjakan soal-soal yang berkaitan dengan materi dan permasalahan-permasalahan yang terjadi dalam kehidupan yang menyebabkan kurang terlatihnya keterampilan berpikir kritis dan kreatif mahasiswa. Mahasiswa juga kurang berani untuk menanyakan materi yang belum dipahami serta kurang berani dalam mengemukakan pendapat yang menyebabkan rendahnya hasil belajar mahasiswa, dimana dilihat dari nilai Ujian Tengah Semester (UTS) mahasiswa yang hanya mampu mencapai nilai rata-rata 58,9.

Berangkat dari kondisi tersebut diperlukan setrategi pembelajaran yang memungkinkan berkembangnya kemampuan berpikir kreatif-kritis dan kemampuan menyampaikan pendapat atau ide, agar mahasiswa mencapai prestasi belajar yang memuaskan. Model pembelajaran probing-prompting merupakan model pembelajaran yang memberikan sejumlah pertanyaan yang diberikan kepada mahasiswa secara acak untuk menuntun mahasiswa mempertahankan pendapatnya berdasarkan pengetahuan dan pemahamannya. Model 
pembelajaran student facilitator and explaining (SFAE) merupakan model pembelajaran dimana mahasiswa berdiskusi dengan kelompoknya kemudian mempresentasikan hasil diskusinya, setiap mahasiswa dituntut untuk bertanya, menyanggah ataupun menanggapi pertanyaan atau jawaban dari mahasiswa lainnya. Jadi, kedua model pembelajaran tersebut sangat cocok untuk diterapkan dalam pembelajaran fisika untuk meningkatkan kreativitas berpikir dan hasil belajar mahasiswa.

Berdasarkan latar belakang masalah yang telah disampaikan di atas maka dapat dikemukakan beberapa rumusan masalah sebagai berikut:

1. Apakah ada perbedaan pengaruh model pembelajaran probing-prompting dan student facilitator and explaining (SFAE) terhadap hasil belajar fisika?

2. Apakah ada perbedaan pengaruh antara mahasiswa yang mempunyai kreativitas berpikir tinggi dan kreativitas berpikir rendah terhadap hasil belajar fisika?

3. Apakah ada interaksi model pembelajaran probing-prompting dan student facilitator and explaining (SFAE) dengan kreativitas berpikir mahasiswa terhadap hasil belajar fisika?

\section{Belajar dan Mengajar}

Menurut Mustaqim dan Abdul Wahib (2010: 62) "belajar adalah proses perubahan. Perubahan-perubahan itu bukan perubahan yang negatif, tetapi perubahan yang positif, yaitu perubahan yang menuju kearah kemajuan atau kearah perbaikan".

Oemar Hamalik (2010: 67) mengartikan "mengajar merupakan proses konservasi kebudayaan, atau penyampaian pengetahuan dan kecakapan atau pengorganisasian lingkungan belajar, atau keaktifan siswa".

\section{Pembelajaran Probing-prompting}

Suherman (dalam Catur Widi Astutik, 2011: 23) menyatakan bahwa "Pembelajaran probing-prompting adalah pembelajaran dengan cara guru menyajikan serangkaian pertanyaan yang sifatnya menuntun dan menggali sehingga terjadi proses berpikir yang mengaitkan pengetahuan tiap siswa dan pengalamannya dengan pengetahuan baru yang sedang dipelajari”. Selanjutnya siswa mengkonstruksi konsep-prinsip dan aturan menjadi pengetahuan baru, dengan demikian pengetahuan baru tidak diberitahukan.

\section{Pembelajaran Student Student Facilitator and Explaining (SFAE)}

Menurut Lie (dalam jurnal Ifan Kurniawan dan Puput Wanarti Rusimamto, 2012: 78) "model Student Facilitator and Explaining (SFAE) merupakan suatu model dimana siswa mempresentasikan ide atau pendapat pada siswa lainnya". "model Student Facilitator and Explaining (SFAE) mempunyai arti model yang menjadikan siswa dapat membuat peta konsep maupun bagan untuk meningkatkan kreativitas siswa dan prestasi belajar siswa" (Suprijono dalam jurnal Ifan Kurniawan dan Puput Wanarti Rusimamto, 2012: 78).

\section{Kreativitas Berpikir Siswa}

Santrock (2008: 366) "Kreativitas ialah kemampuan berpikir tentang sesuatu dengan cara baru dan tidak biasa dan menghasilkan solusi yang unik atas suatu problem". Fatur Rohim et al (dalam Heru Wicaksono, 2013: 36) "berpikir kreatif merupakan salah satu tahapan berpikir tingkat tinggi yang diperlukan dalam kehidupan masyarakat, dan manusia selalu dihadapkan pada permasalahan sehingga diperlukan kreativitas untuk memecahkanya.

\section{Hipotesis Penelitian}

Berdasarkan kajian pustaka dan kerangka berfikir di atas, maka peneliti mengajukan hipotesis penelitian sebagai berikut:

1. Ada perbedaan pengaruh model pembelajaran probing-prompting dan model Student Facilitator and Explaining (SFAE) terhadap hasil belajar fisika.

2. Ada perbedaan pengaruh antara siswa yang mempunyai kreativitas berpikir tinggi dan kreativitas berpikir rendah terhadap hasil belajar fisika. 
3. Ada interaksi antara model pembelajaran probing-prompting dan Student Facilitator and Explaining (SFAE) dengan kreativitas berpikir siswa terhadap hasil belajar fisika.

\section{METODE}

Penelitian ini dilaksanakan di Prodi Teknik Informatika Tahun Akademik 2014/2015. Metode penelitian yang digunakan adalah metode eksperimen dan metode eksperimen ini menggunakan dua kelas, yaitu kelas eksperimen II (A) dan kelas eksperimen II (B). Penelitian dilakukan dengan menggunakan Desain Anava dengan desain faktorial $2 \times 2$.

Variabel yang digunakan pada penelitian ini terdiri dari satu variabel bebas, satu variabel moderat, dan satu variabel terikat yaitu: 1) Variabel bebas yaitu model pembelajaran Probingprompting $\left(\mathrm{A}_{1}\right)$, model pembelajaran student facilitator and explaining (SFAE) $\left(\mathrm{A}_{2}\right)$. Variabel moderator yaitu kreativitas berpikir. Kreativitas berpikir mahasiswa meliputi tinggi dan rendah. Variabel terikat yaitu hasil belajar mahasiswa pada ranah kognitif.

Populasi dalam penelitian ini adalah semua mahasiswa semester II Tahun Akademi 2014/2015 yang berjumlah 34 mahasiswa. Sebagai sampel penelitian berjumlah 34 mahasiswa terdiri dari satu kelas sebagai kelas dengan model pembelajaran Probing-prompting dengan jumlah mahasiswa 16 dan kelas lain adalah kelas dengan model pembelajaran student facilitator and explaining (SFAE) dengan jumlah mahasiswa 18.

Teknik pengambilan sampel yang digunakan dalam penelitian ini adalah teknik simple random sampling dengan pengambilan secara acak tanpa memperhatikan strata yang ada dalam populasi. Data dalam penelitian ini terdiri dari kemampuan awal, kreativitas berpikir, dan hasil belajar mahasiswa. Data kemampuan awal mahasiswa diperoleh berdasarkan observasi dari dokumen nilai UTS untuk uji prasyarat sampel. Data kemampuan kreativitas berpikir mahasiswa diperoleh berdasarkan tes kemampuan kreativitas berpikir. Hasil belajar fisika mahasiswa diperoleh berdasarkan hasil quiz.

Instrumen penelitian yang digunakan meliputi Instrumen Pembelajaran, Silabus, Rencana Pelaksanaan Pembelajaran (RPP), dan Instrumen Pengambilan Data adalah Soal tes kognitif, Soal tes kreativitas berpikir. Adapun uji instrumen dari penelitian ini meliputi: Validitas, Reliabilitas, Tingkat kesukaran, Daya pembeda (DP).

Analisis data pada penelitian ini meliputi analisa deskriptif dan analisa inferensial. Data keadaan awal mahasiswa yang diperoleh diuji normalitas dan homogenitasnya. Selanjutnya data yang normal dan homogen dianalisis dengan menggunakan analisis variansi dua jalan dengan isi sel tak sama. Langkahlangkahnya adalah : 1) Uji Kesamaan Keadaan Awal/prasayrat sampel menggunakan Uji Normalitas dengan metode Liliefors dan Uji Homogenitas dengan menggunakan Uji $\mathrm{F}, 2$ ) Uji Hipotesis, 3) Uji Anava, 4) Uji Lanjut Anava dengan uji komparasi ganda menggunakan metode Scheffe.

\section{HASIL PENELITIAN}

\section{Data Hasil Penelitian}

\section{a. Data Kemampuan Awal Mahasiswa Sebelum Diberi Perlakuan}

Data kemampuan awal yang digunakan dalam penelitian ini diperoleh dari nilai Ujian Tengah Semester (UTS). Nilai tersebut digunakan untuk mengetahui kemampuan awal kedua kelas sama atau tidak. Deskripsi data kemampuan awal disajikan pada Tabel 1.

Tabel 1. Data Kemampuan Awal

\begin{tabular}{|l|c|c|c|c|c|c|}
\hline \multicolumn{1}{|c|}{ Kelompok } & Kelas & $\begin{array}{c}\text { Jumlah } \\
\text { Mhs }\end{array}$ & $\begin{array}{c}\text { Nilai } \\
\text { tertinggi }\end{array}$ & $\begin{array}{c}\text { Nilai } \\
\text { terendah }\end{array}$ & $\begin{array}{c}\text { Rata- } \\
\text { rata }\end{array}$ & SD \\
\hline Eksperimen I & A & 18 & 80 & 45 & 60,00 & 10,29 \\
\hline Eksperimen II & B & 16 & 75 & 50 & 57,81 & 7,74 \\
\hline
\end{tabular}

Tabel 2. Distribusi Frekuensi Kemampuan Awal Sebelum Diberi Perlakuan Kelompok Eksperimen I

\begin{tabular}{|c|c|c|}
\hline Interval Kelas & Frekuensi Mutlak & Frekuensi Relatif \\
\hline $45-50$ & 5 & $27,78 \%$ \\
\hline $51-56$ & 3 & $16,67 \%$ \\
\hline $57-62$ & 3 & $16,67 \%$ \\
\hline $63-68$ & 2 & $11,11 \%$ \\
\hline $69-74$ & 3 & $16,67 \%$ \\
\hline $75-80$ & 2 & $11,11 \%$ \\
\hline Jumlah & 18 & $100 \%$ \\
\hline
\end{tabular}




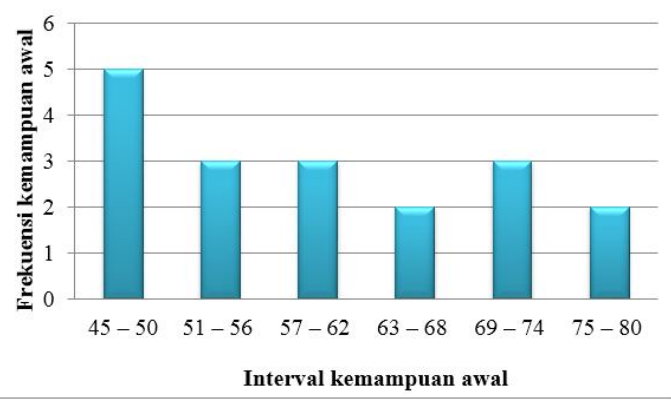

Gambar 1. Histogram Kemampuan Awal Kelompok Eksperimen I

Tabel 3. Distribusi Frekuensi Kemampuan Awal Sebelum Diberi Perlakuan Kelompok Eksperimen II

\begin{tabular}{|c|c|c|}
\hline Interval Kelas & Frekuensi Mutlak & Frekuensi Relatif \\
\hline $50-55$ & 9 & $56,25 \%$ \\
\hline $56-61$ & 3 & $18,75 \%$ \\
\hline $62-67$ & 2 & $12,5 \%$ \\
\hline $68-73$ & 1 & $6,25 \%$ \\
\hline $74-79$ & 1 & $6,25 \%$ \\
\hline Jumlah & 16 & $100 \%$ \\
\hline
\end{tabular}

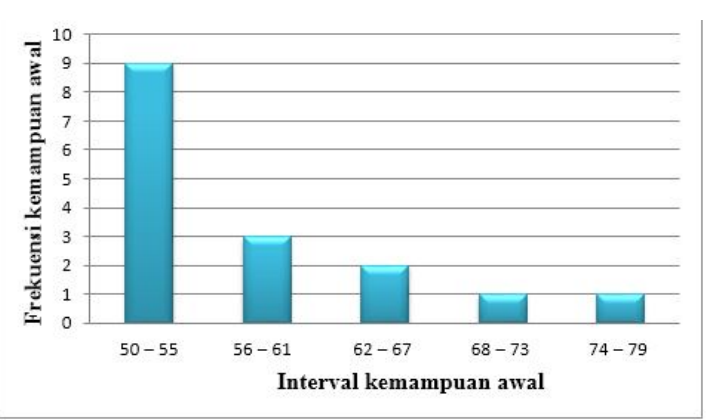

Gambar 2. Histogram Kemampuan Awal Kelompok Eksperimen II

b. Data Hasil Belajar Mahasiswa Tabel 4. Data Hasil Belajar Mahasiswa

\begin{tabular}{c|c|c|c|c|c|c|}
\hline \multirow{2}{*}{ Kelompok } & \multirow{2}{*}{ Kelas } & \multirow{2}{*}{$\begin{array}{c}\text { Jumlah } \\
\text { Mhs }\end{array}$} & & \multicolumn{4}{|c|}{ Hasil Belajar } \\
\cline { 4 - 7 } & & & Maksimal & Minimal & Mean & SD \\
\hline Eksperimen I & $\mathrm{A}$ & 18 & 95 & 40 & 72,78 & 12,86 \\
\hline Eksperimen II & $\mathrm{B}$ & 16 & 100 & 55 & 76,56 & 11,06 \\
\hline
\end{tabular}

Tabel 5. Distribusi Frekuensi Hasil Belajar Kelompok Eksperimen I

\begin{tabular}{|c|c|c|c|c|}
\hline \multicolumn{2}{|c|}{ Interval Kelas } & \multicolumn{2}{|c|}{ Frekuensi Mutlak } & rekuensi Relatif \\
\hline \multicolumn{2}{|c|}{$40-49$} & \multicolumn{2}{|c|}{1} & $5,56 \%$ \\
\hline \multicolumn{2}{|c|}{$50-59$} & \multicolumn{2}{|l|}{1} & $5,56 \%$ \\
\hline \multicolumn{2}{|c|}{$601-60$} & 3 & & $1667 \%$ \\
\hline \multirow{2}{*}{$\begin{array}{c}\text { Kategori } \\
\text { Kreativitas }\end{array}$} & \multicolumn{2}{|c|}{ Jumlah Responden } & \multicolumn{2}{|c|}{ Rata-rata Hasil Belajar } \\
\hline & Eksperimen I & Eksperimen II & Eksperimen I & Eksperimen II \\
\hline Tinggi & 11 & 7 & 36 & 70 \\
\hline Rendah & 7 & 9 & 82,14 & 72,22 \\
\hline
\end{tabular}

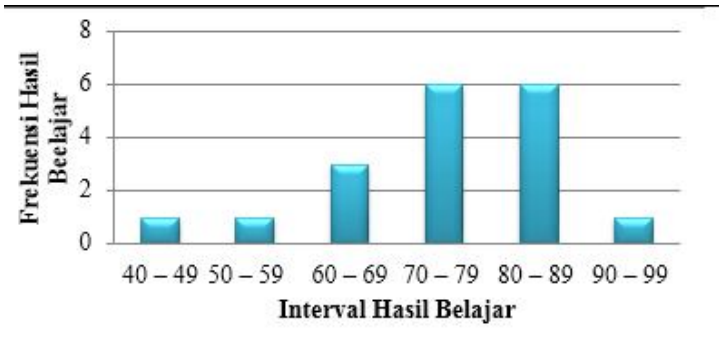

Gambar 3. Histogram Hasil Belajar Kelompok Eksperimen I

Tabel 6. Distribusi Frekuensi Hasil Belajar Kelompok Eksperimen II

\begin{tabular}{|c|c|c|}
\hline Interval Kelas & Frekuensi Mutlak & Frekuensi Relatif \\
\hline $55-64$ & 2 & $12,5 \%$ \\
\hline $65-74$ & 2 & $12,5 \%$ \\
\hline $75-84$ & 8 & $50 \%$ \\
\hline $85-94$ & 3 & $18,75 \%$ \\
\hline $95-104$ & 1 & $6,25 \%$ \\
\hline Jumlah & 16 & $100 \%$ \\
\hline
\end{tabular}

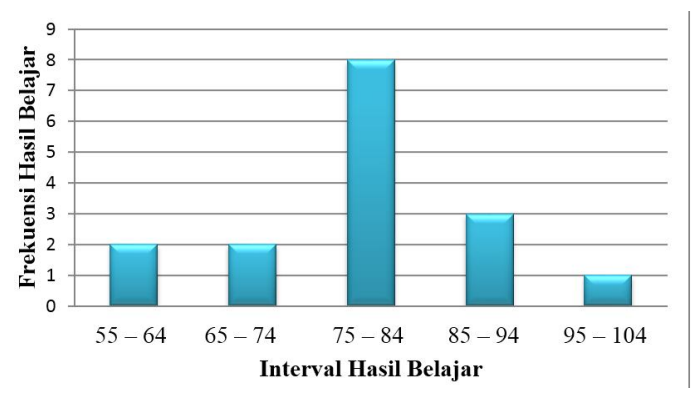

Gambar 4. Histogram Hasil Belajar Kelompok Eksperimen II

\section{c. Data Kreativitas Mahasiswa}

Tabel 7. Hasil Pengkategorian Kreativitas Mahasiswa

\begin{tabular}{|c|c|c|c|c|}
\hline \multirow{2}{*}{$\begin{array}{c}\text { Kategori } \\
\text { Kreativitas }\end{array}$} & \multicolumn{2}{|c|}{ Jumlah Responden } & \multicolumn{2}{c|}{ Rata-rata Hasil Belajar } \\
\cline { 2 - 5 } & Eksperimen I & Eksperimen II & Eksperimen I & Eksperimen II \\
\hline Tinggi & 11 & 7 & 36 & 70 \\
\hline Rendah & 7 & 9 & 82,14 & 72,22 \\
\hline
\end{tabular}

Tabel 8. Distribusi Frekuensi Kreativitas Kelompok Eksperimen I

\begin{tabular}{|c|c|c|}
\hline Interval Kelas & Frekuensi Mutlak & Frekuensi Relatif \\
\hline $40-44$ & 3 & $16,67 \%$ \\
\hline $45-49$ & 0 & $0 \%$ \\
\hline $50-54$ & 4 & $22,22 \%$ \\
\hline $55-59$ & 6 & $33,33 \%$ \\
\hline $60-64$ & 4 & $22,22 \%$ \\
\hline $65-69$ & 1 & $5,56 \%$ \\
\hline Jumlah & 18 & $100 \%$ \\
\hline
\end{tabular}




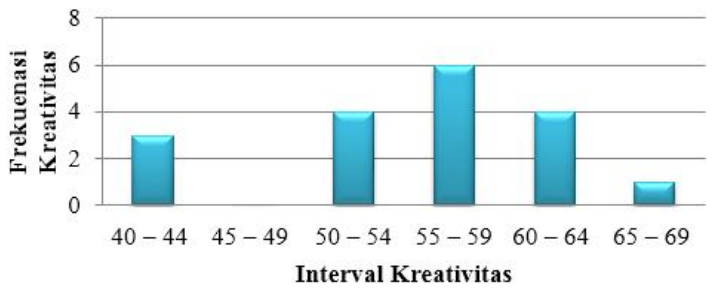

Gambar 5. Histogran Kreativitas Siswa Kelompok Eksperimen I

Tabel 9. Distribusi Frekuensi Kreativitas Mahsiswa Kelompok Eksperimen II

\begin{tabular}{|c|c|c|}
\hline Interval Kelas & Frekuensi Mutlak & Frekuensi Relatif \\
\hline $38-44$ & 8 & $50 \%$ \\
\hline $45-51$ & 3 & $18,75 \%$ \\
\hline $52-58$ & 3 & $18,75 \%$ \\
\hline $59-65$ & 1 & $6,25 \%$ \\
\hline $66-72$ & 1 & $6,25 \%$ \\
\hline Jumlah & 16 & $100 \%$ \\
\hline
\end{tabular}

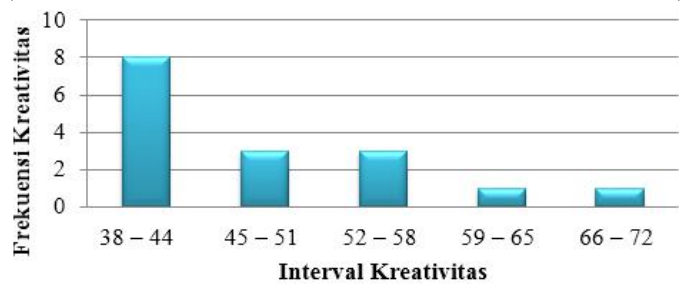

Gambar 6 Histogran Kreativitas Mahasiswa Kelompok Eksperimen II

Data Hasil Belajar Fisika Mahasiswa dengan Model Pembelajaran Probing-Prompting untuk Kreativitas Berfikir Tinggi.

Tabel 10. Distribusi Frekuensi

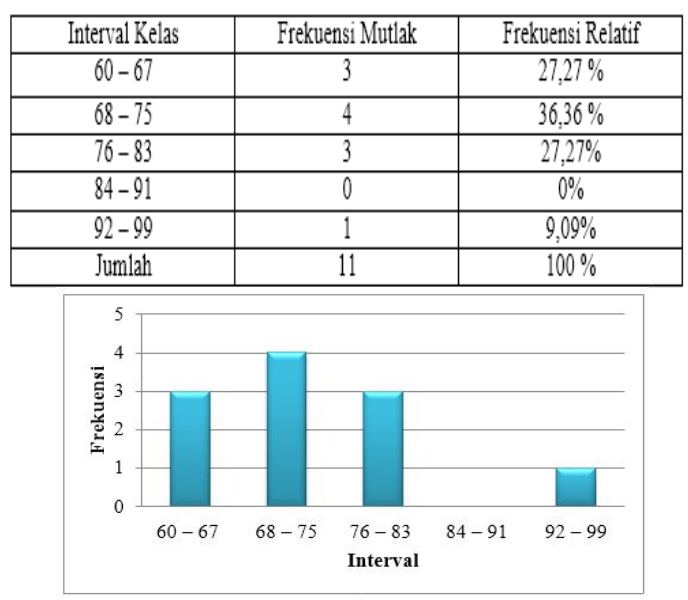

Gambar 7. Histogram Distribusi Frekuensi
Tabel 11. Distribusi Frekuensi

\begin{tabular}{|c|c|c|}
\hline Interval Kelas & Frekuensi Mutlak & Frekuensi Relatif \\
\hline $40-51$ & 1 & $14,29 \%$ \\
\hline $52-63$ & 1 & $14,29 \%$ \\
\hline $64-75$ & 2 & $28,57 \%$ \\
\hline $76-87$ & 3 & $42,86 \%$ \\
\hline Jumlah & 7 & $100 \%$ \\
\hline
\end{tabular}

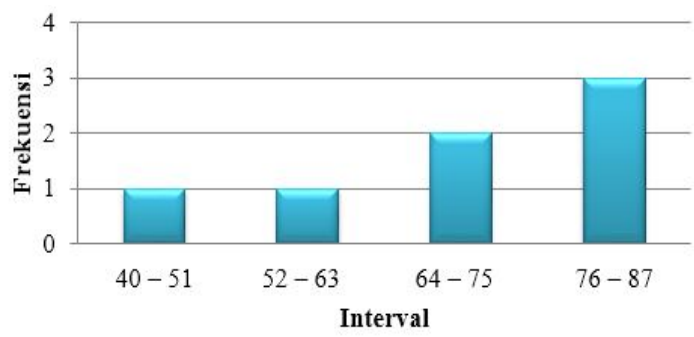

Gambar 8. Histogran Distribusi Frekuensi Data Hasil Belajar Fisika Mahasiswa dengan Model Pembelajaran Student Facilitator and Explaining untuk Kreativitas Berfikir Tinggi.

Tabel 12. Distribusi Frekuensi

\begin{tabular}{|c|c|c|}
\hline Interval Kelas & Frekuensi Mutlak & Frekuensi Relatif \\
\hline $70-77$ & 3 & $42,86 \%$ \\
\hline $78-85$ & 2 & $28,57 \%$ \\
\hline $86-93$ & 1 & $14,29 \%$ \\
\hline $94-101$ & 1 & $14,29 \%$ \\
\hline Jumlah & 7 & $100 \%$ \\
\hline
\end{tabular}

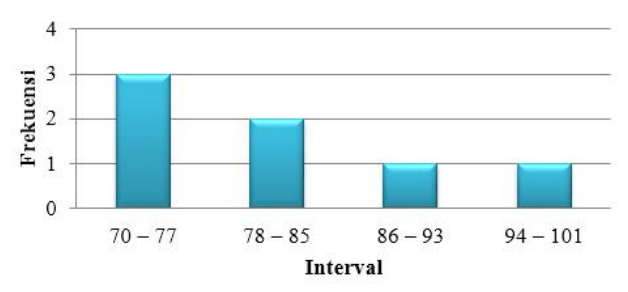

Gambar 9. Histogram Distribusi Frekuensi

Data Hasil Belajar Fisika Mahasiswa dengan Model Pembelajaran Student Facilitator and Explaining untuk Kreativitas Berfikir Rendah.

Tabel 13. Distribusi Frekuensi

\begin{tabular}{|c|c|c|}
\hline Interval Kelas & Frekuensi Mutlak & Frekuensi Relatif \\
\hline $55-61$ & 2 & $22,22 \%$ \\
\hline $62-68$ & 1 & $11,11 \%$ \\
\hline $69-75$ & 3 & $33,33 \%$ \\
\hline $76-82$ & 2 & $22,22 \%$ \\
\hline $83-89$ & 1 & $11,11 \%$ \\
\hline Jumlah & 9 & $100 \%$ \\
\hline
\end{tabular}




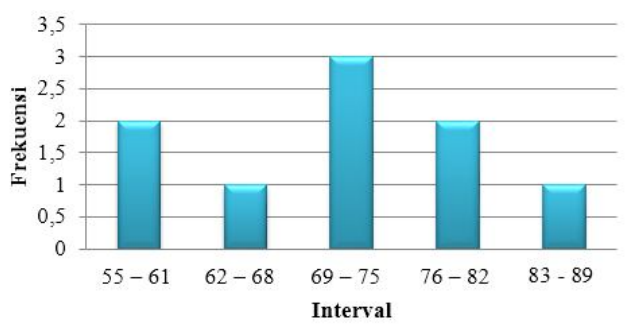

Gambar 10. Histogram Distribusi Frekuensi

\section{HASIL PENGUJIAN HIPOTESIS}

1. Data Hasil Uji Prasyarat Sampel

a. Uji Normalitas Kemampuan Awal

Tabel 14. Uji Normalitas Kemampuan Awal

\begin{tabular}{|l|c|c|c|}
\hline \multicolumn{1}{|c|}{ Kelompok kelas } & $\mathrm{L}_{0 \mathrm{~s}}$ & $\mathrm{~L}_{\mathrm{a} \text { an }}$ & Keterangan \\
\hline Probing-Prompting & 0,13 & 0,200 & Normal \\
\hline Student Facilitator and Explaining & 0,20 & 0,213 & Normal \\
\hline
\end{tabular}

b. Uji Homogenitas Kemampuan Awal Tabel 15. Uji Homogenitas Kemampuan Awal

\begin{tabular}{|lc|c|c|c|}
\hline \multicolumn{2}{|c|}{ Kelompok Kelas } & $\mathrm{F}_{\mathrm{a}}$ & $\mathrm{F}_{\mathrm{t}}$ & Keterangan \\
\hline $\begin{array}{l}\text { Probing-Prompting dan Student } \\
\text { Facilitator and Explaining }\end{array}$ & 0,566 & 2,37 & Homogen \\
\hline
\end{tabular}

2. Data Hasil Uji Prasyarat Analisis

a. Uji Normalitas

Tabel 16. Uji Normalitas Hasil Belajar Mahasiswa

\begin{tabular}{|l|c|c|l|l|}
\hline \multicolumn{1}{|c|}{ Kelas } & $\mathrm{L}_{\text {obs }}$ & $\mathrm{L}_{\text {tabel }} / \mathrm{DK}$ & Keputusan & Kesimpulan \\
\hline Eksperimen I & 0,13 & 0,200 & $\mathrm{H}_{0}$ diterima & Normal \\
\hline Eksperimen II & 0,11 & 0,213 & $\mathrm{H}_{0}$ diterima & Normal \\
\hline $\begin{array}{l}\text { Kemampuan Kreativitas } \\
\text { berfikir Tinggi }\end{array}$ & 0,17 & 0,200 & $\mathrm{H}_{0}$ diterima & Normal \\
\hline $\begin{array}{l}\text { Kemampuan Kreativitas } \\
\text { Berfikir Rendah }\end{array}$ & 0,18 & 0,213 & $\mathrm{H}_{0}$ diterima & Normal \\
\hline
\end{tabular}

b. Uji Homogenitas

Tabel 18 Uji Homogenitas Hasil Belajar Mahasiswa

\begin{tabular}{|l|c|c|c|c|}
\hline \multicolumn{1}{|c|}{ Kelas } & $\mathrm{F}_{\mathrm{l}}$ & $\mathrm{F}_{\mathrm{t}}$ & $\begin{array}{c}\text { Hasil } \\
\text { Uji }\end{array}$ & $\begin{array}{c}\text { Ke } \\
\text { simpulan }\end{array}$ \\
\hline Eksperimen I dan II & 0,79 & 2,31 & $\mathrm{~F}_{\mathfrak{L}}<\mathrm{F}_{\mathrm{t}}$ & Homogen \\
\hline $\begin{array}{l}\text { Kemampuan Kreativitas } \\
\text { berfikir Tinggi dan rendah }\end{array}$ & 1,49 & 2,30 & $\mathrm{~F}_{\mathfrak{L}}<\mathrm{F}_{\mathrm{i}}$ & Homogen \\
\hline
\end{tabular}

c. Uji Analisis Varian Anava

Tabel 19 Rangkuman Anava

\begin{tabular}{|l|c|c|c|c|c|c|}
\hline Sumber & JK & Dk & RK & Fobs & Fa & Ho \\
\hline Model pembelajaran (A) & 197,292 & 1 & 197,292 & 1,419 & 4,17 & Diterima \\
\hline Kreativitas (B) & 429,27 & 1 & 429,27 & 3,087 & 4,17 & Diterima \\
\hline Interaksi (AB) & 59,122 & 1 & 59,122 & 0,425 & 4,17 & Diterima \\
\hline Galat & 4171,15 & 30 & & - & - & - \\
\hline Total & 4856,834 & 33 & - & - & - & - \\
\hline
\end{tabular}

Hasil uji anava untuk faktor model diperoleh $\mathrm{F}_{\mathrm{obs}}<\mathrm{F}_{\mathrm{a}}(4,38<4,17)$ maka $\mathrm{H}_{0 \mathrm{~A}}$ diterima dan $\mathrm{H}_{1 \mathrm{~A}}$ ditolak. Sehingga diketahui tidak ada perbedaan pengaruh antara model Probing-Prompting dan Student Fasilitator and Explaining. Hal ini terlihat pada rata-rata nilainya yang tidak terlalu jauh yaitu 65,56 dan 70,63 dari 20 soal yang diberikan pada mahasiswa yang berupa soal pilihan ganda.

Model pembelajaran ProbingPrompting, dosen menyajikan serangkaian pertanyaan yang sifatnya menuntun dan menggali sehingga terjadi proses berpikir yang mengaitkan pengetahuan setiap mahasiswa dan pengalamannya dengan pengetahuan baru yang sedang dipelajari, sehingga mahasiswa akan termotivasi untuk memahami lebih mendalam suatu masalah hingga mencapai suatu jawaban yang dituju.

Model pembelajaran Student Fasilitator and Explaining dimana mahasiswa dalam kelasnya mendapatkan tugas yang berbeda antara kelas satu dengan yang lainnya tetapi tidak menyimpang dengan materi yang telah diajarkan sebelumnya. Masing-masing kelas bertanggung jawab untuk mengorganisasikan kelasnya dalam mencari informasi tentang tugas yang diberikan dosen, selanjutnya mendiskusikan masalah tersebut kemudian mempresentasikan hasil diskusinya dan memberikan kesempatan kepada kelas lain untuk bertanya.

Berdasarkan hasil data penelitian model pembelajaran Probing-Prompting dan Student Facilitator and Explaining menunjukkan tidak ada perbedaan pengaruh kreativitas tinngi dan rendah terhadap hasil belajar fisika. Berdasarkan data induk penelitian menunjukkan bahwa rata-rata hasil belajar mahasiswa yang memiliki kreativitas berpikir tinggi adalah 77,5 dan mahasiswa yang mempunyai kreativitas berpikir rendah adalah 71,25 , berdasarkan uraian tersebut menunjukkan bahwa mahasiswa yang memiliki kreativitas berpikir tinggi dan rendah tidak memiliki selisih nilai yang jauh. Dari hasil uji anava diperoleh $\mathrm{F}_{\mathrm{obs}}=3,69<4,17$ sehingga $\mathrm{H}_{0 \mathrm{~B}}$ diterima dan $\mathrm{H}_{1 в}$ ditolak. 
Hasil uji anava yang telah dilakukan menunjukkan bahwa $\quad \mathrm{F}_{\mathrm{obs}}=0,04<$ 4,17, sehingga $\mathrm{H}_{0 \mathrm{AB}}$ diterima dan $\mathrm{H}_{1 \mathrm{AB}}$ ditolak. Ini berarti tidak terdapat interaksi antara model Probing-Prompting dan Student Facilitator and Explaining dengan kreativitas berpikir terhadap hasil belajar mahasiswa. Hal ini berarti bahwa tingkat kreativitas berpikir mahasiswa dan model pembelajaran tidak memberikan perbedaan hasil belajar yang signifikan.

Tidak adanya interaksi tersebut bisa dikatakan bahwa anak yang memiliki tingkat kreativitas berpikir tinggi walaupun menggunakan model pembelajaran yang berbeda akan memiliki hasil belajar yang selalu tinggi jika dibandingkan anak yang memiliki kreativitas berpikir rendah dan banyak yang nilainya berada di atas ratarata kelas, begitupun sebaliknya anak yang memiliki tingkat kreativitas berpikir rendah dengan menggunakan model pembelajaran yang berbeda akan memperoleh hasil belajar yang rendah bila dibanding anak yang kreativitas berpikirnya tinggi dan nilainya selalu di bawah rata-rata kelas. Dapat disimpulkan bahwa tidak ada pengaruh atau interaksi karena diperoleh hasil yang sama.

\section{KESIMPULAN}

1. Tidak ada perbedaan pengaruh model pembelajaran Probing-Prompting dan Student Facilitator and Explaining terhadap hasil belajar fisika.

2. Tidak ada perbedaan pengaruh kreativitas mahasiswa tinggi dan rendah terhadap hasil belajar fisika.

3. Tidak ada interaksi antara model pembelajaran Probing-Prompting dan Student Facilitator and Explaining dengan kreativitas mahasiswa terhadap hasil belajar fisika.

\section{DAFTAR PUSTAKA}

Agus Suprijono. 2012. Cooperative Learning Teori dan Aplikasi Pakem. Yogyakarta: Pustaka Pelajar.

Anita Lie. 2008. Cooperative Learning Mempraktikkan Cooperative Learning diruang - ruang kelas. Jakarta: PT Gramedia Widiasarana Indonesia.

Budiyono. 2004. Statistik Untuk Penelitian.

Surakarta: Sebelas Maret University Press. 2009. Statistik Untuk Penelitian. Surakarta: UNS Press.

Catur Widi Astutik. 2011. Penerapan Model Pembelajaran ProbingPrompting untuk Meningkatkan Aktivitas dan Prestasi Belajar Siswa Kelas VII SMP Negeri 1 Wonoasri Tahun Pelajaran 2010/2011. Skipsi tidak diterbitkan. Madiun. Program Studi Pendidikan Fisika, Fakultas Pendidikan Matematika dan Ilmu Pengetahuan Alam IKIP PGRI Madiun.

Eko Putro Widoyoko. 2012. Teknik Penyusunan Instrumen Penelitian. Yogyakarta: Pustaka Peajar

Ifan Kurniawan dan Puput Winarti Rusmianto. 2012. Pengembangan Perangkat Pembelajaran Metode Student Facilitator And Explaining pada Standar Kompetensi Menjelaskan dasar dasar Sinyal Video. (online) Jurnal unesa, (http://ejournal.unesa.ac.id, diakses 20 September 2013).

La Iru dan La Ode Safiun Arihi. 2012. Analisis Penerapan Pendekatan, Metode, Strategi dan Model model Pembelajaran. DIY: Multipresindo.

Nana Syaodih Sukmadinata. 2009. Landasan Psikologi Proses Pendidikan. Bandung: PT. Remaja Rosdakarya.

Oemar Hamalik. 2004. Proses Belajar Mengajar. Jakarta: PT. Bumi Aksara. 
2010. Proses Belajar Mengajar. Jakarta: PT. Bumi Aksara.

Suharsimi Arikunto. 2007. Dasar-dasar Evaluasi Pendidikan. Jakarta: PT Bumi Aksara.

- 2010. Prosedur Penelitian Suatu Pendekatan Praktik. Jakarta: PT Rineka Cipta.

Sugiyono. 2010. Metode Penelitian Pendidikan Pendekatan Kuantitatif, Kualitatif Dan $R \& D$. Bandung: Alfabeta.

Utami Munandar. 2010. Pengembangan Kreatifitas Anak Berbakat. Jakarta: PT Rineka Cipta. 